\title{
SEPSIS AND CARDIORENAL SYNDROME: ETIOPATHOGENESIS, DIAGNOSIS AND TREATMENT
}

Dejan Petrovic ${ }^{1}$ Željko Mijailovic ${ }^{2}$, Biljana Popovska², Vladimir Miloradović3, Predrag Djurdjević4

${ }^{1}$ Clinic for Urology and Nephrology, Clinical Center Kragujevac, Kragujevac

${ }^{2}$ Infectious Diseases Clinic, Clinical Center Kragujevac, Kragujevac

${ }^{3}$ Clinic for Cardiology, Clinical Center Kragujevac, Kragujevac

${ }^{4}$ Clinic for Haematology, Clinical Center Kragujevac, Kragujevac, Serbia

\author{
SEPSA I KARDIO-RENALNI SINDROM: \\ ETIOPATOGENEZA, DIJAGNOSTIKA I LEČENJE \\ Dejan Petrović ${ }^{1}$, Željko Mijailović2, Biljana Popovska², Vladimir Miloradović3, Predrag Đurđević ${ }^{4}$ \\ ${ }^{1}$ Centar za urologiju i nefrologiju, Klinika za urologiju i nefrologiju, KC Kragujevac \\ ${ }^{2}$ Klinika za infektivne bolesti, KC Kragujevac, Kragujevac \\ ${ }^{3}$ Klinika za kardiologiju, KC Kragujevac, Kragujevac \\ ${ }^{4}$ Klinika za hematologiju, KC Kragujevac, Kragujevac, Srbija
}

Received / Primljen: 24.08.2013.

Accepted / Prihvaćen: 12.09.2013.

\begin{abstract}
Introduction: Sepsis is the most common cause of acute renal failure in intensive care units.

Aim: This study aimed to analyse the etiopathogenesis of sepsis and the clinical significance of early detection and timely treatment of sepsis in intensive care units.

Method: We analysed literature and clinical studies addressing the pathogenesis, diagnosis and treatment of sepsis syndrome.

Results: There was a 1.5\% increase in the number of patients with sepsis over one year. Severe sepsis is defined as sepsis with hypotension, hypoperfusion and organ dysfunction. Sepsis is characterised by activation of the patient's immune system and enhancement of the creation of mediators that play an important role in the development of multiple organ system failure in patients with sepsis. The strategy for preventing acute renal failure in patients with sepsis includes early targeted therapy (in the first 6 hours), which consists of an early increase in blood volume circulating fluids (at least $20 \mathrm{ml} / \mathrm{kg}$ crystalloid in the first hour). Initial therapy should be achieved by central venous pressure of $8-12 \mathrm{mmHg}$, mean arterial blood pressure greater than $65 \mathrm{mmHg}$, urine output greater than $0.5 \mathrm{ml} / \mathrm{kg} / \mathrm{h}$ and mixed venous blood saturation of oxygen greater than $70 \%$. The ventilation strategy to protect the lungs and kidneys in patients on mechanical ventilation includes a tidal volume of $6 \mathrm{ml} / \mathrm{kg}$ and an end-inspiratory pressure plateau less than $30 \mathrm{cmH}_{2} \mathrm{O}$. To remove a mediator from the serum of patients, high-volume haemofiltration and continuous haemodiafiltration with PMMA are used.

Conclusion: Early follow-up and early implementation of targeted therapies play a key role in preventing the development of acute heart and kidney damage.
\end{abstract}

Key words: sepsis, cardio-renal syndrome, dialysis therapy

\section{SAŽETAK}

Uvod. Sepsa je najčešći uzrok akutnog oštećenja bubrega u jedinicama intenzivnog lečenja.

Cilj. Rad je imao za cilj da analizira etiopatogenezu sepse i klinički značaj ranog otkrivanja i pravovremenog lečenja sepse kod bolesnika u jedinicama intenzivnog lečenja.

Metodologija. Analizirani su stručni radovi i kliničke studije koje se bave etiopatogenezom, dijagnostikovanjem $i$ lečenjem sindroma sepse.

Rezultati. Jednogodišnja stopa porasta broja bolesnika sa sepsom iznosi 1.5\%. Teška sepsa se definiše kao sepsa sa hipotenzijom, hipoperfuzijom i poremećajem funkcije organa. Sepsa se odlikuje aktivacijom imunskog sistema bolesnika i pojačanim stvaranjem pro- $i$ antiinflamatornih medijatora. Pojačan $i$ neregulisan odgovor imunskog sistema i pojačano stvaranje medijatora imaju značajnu ulogu u razvoju insuficijencije više sistema organa kod bolesnika sa sepsom. Strategija za prevenciju razvoja akutnog oštećenja bubrega kod bolesnika sa sepsom uključuje ranu ciljnu terapiju (u prvih 6 sati), koja se sastoji u ranoj pojačanoj nadoknadi zapremine krvi u cirkulaciji tečnostima (najmanje $20 \mathrm{ml} / \mathrm{kg}$ kristaloida u prvom satu). Početnom terapijom treba da se postigne centralni venski pritisak od 8-12 $\mathrm{mmHg}$, srednji arterijski krvni pritisak veći od $65 \mathrm{mmHg}$, diureza veća od $0.5 \mathrm{ml} / \mathrm{kg} / \mathrm{h}$ i zasićenost centralne venske krvi kiseonikom veća od $70 \%$. Strategija ventilacije za zaštitu pluća $i$ bubrega kod bolesnika na mehaničkoj ventilaciji uključuje tajdl volumen od $6 \mathrm{ml} / \mathrm{kg}$ i pritisak end-inspiratornog platoa manji od $30 \mathrm{CmH}_{2} \mathrm{O}$. Za odstranjivanje medijatora iz seruma bolesnika koriste se visoko-volumenska hemofiltracija $i$ kontinuirana hemodijafiltracija sa PMMA membranom.

Zaključak. Rano praćenje bolesnika i primena rane ciljne terapije imaju ključnu ulogu u sprečavanju razvoja akutnog oštećenja srca i bubrega.

Ključne reči: sepsa, kardio-renalni sindrom, dijalizna terapija

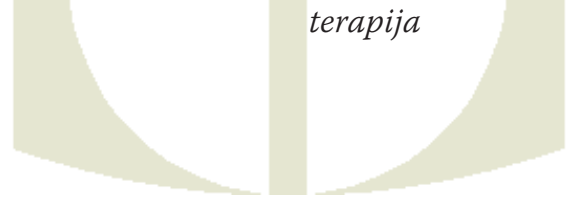

UDK: 616.94 / Ser J Exp Clin Res 2013; 14 (4): 181-187 DOI: $10.5937 /$ SJECR4363 


\section{INTRODUCTION}

Cardiorenal syndrome is a pathophysiological disorder of the heart and kidneys, where acute or chronic dysfunction of one organ stimulates acute or chronic dysfunction in the other [1-6]. We distinguish five types of cardiorenal syndrome, of which Type 5 CRS causes severe sepsis and septic shock and leads to acute disorders of the heart and kidneys (septic cardiorenal syndrome) [1-6]. Due to the complexity and severity of acute kidney injury (AKI) (sepsis and multiple organ dysfunction syndrome), patients in intensive care units require a team approach, skilled staff and technical equippedness, continuous and enhanced cooperation between a nephrologist and intensivist anaesthesiologist and the use of a new treatment plan, which includes multiple organ support therapy [7]. Several of the main tasks of an intensivist physician in the ICU include detecting sepsis early, treating septic patients by achieving optimal blood volume status and preventing the development of cardiorenal syndrome [7].

\section{Sepsis: definition, aetiopathogenesis and clinical significance}

Sepsis is a serious clinical syndrome in medicine and a major health problem in both developed and underdeveloped countries. The number of septic patients has grown by $1.5 \%$ in the past year, and 934,000 patients in the USA developed sepsis in 2010. Regardless of technological advances (dialysis supportive therapy, respiratory supportive therapy), the mortality rate of patients with severe sepsis remains high at $30-50 \%$, and the cost of one-year treatment of such patients exceeds 50 trillion USD [8].

\section{Definition}

Bacteraemia is the presence of bacteria in the patient's blood. A patient's response to an infection is systemic inflammatory response syndrome (SIRS) and is defined as the presence of two or more related criteria: body temperature $>38^{\circ} \mathrm{C}$ or $<36^{\circ} \mathrm{C}$, heart rate $>90$ beats per minute, respiratory rate $>20$ breaths per minute or arterial partial pressure of $\mathrm{pCO}_{2}$ less than $32 \mathrm{mmHg}$, white blood cell count $>12 \times 10^{9} / \mathrm{mL}$ or $<4 \times 10^{9} / \mathrm{mL}$ or $>10 \%$ immature neutrophils (band forms) $[9,10]$. Sepsis is defined as SIRS with a confirmed infection. Severe sepsis is defined as sepsis accompanied with hypotension, hypoperfusion, organ dysfunction (serum lactate $>2 \mathrm{mmol} / \mathrm{L}$ ), altered mental status, capillary volume recharge $\geq 3 \mathrm{~s}$, diuresis $<0.5 \mathrm{~mL}$ $/ \mathrm{kg} / \mathrm{h}$, serum creatinine levels increase of $\geq 26.4 \mu \mathrm{mol} / \mathrm{L}$, platelet count $<100 \times 10^{9} / \mathrm{mL}$ or disseminated intravascular coagulopathy, acute lung injury/acute respiratory distress syndrome and heart disorder (cardiac index $<2.2$ $\left.\mathrm{L} / \mathrm{min} / \mathrm{m}^{2}\right)[9,10]$. Septic shock is defined as severe sepsis with hypotension, with no improvement following intravenous infusion therapy (i.e., restoring fluid volume in circulation), evidence for hypoperfusion or organ dysfunction, mean arterial blood pressure $<60 \mathrm{mmHg}(<80 \mathrm{mmHg}$ in previously hypertensive patients) after crystalloids infusion (0.9\% saline) in the dose range of $40-60 \mathrm{~mL} / \mathrm{kg}$ in the first hour or pulmonary capillary filling pressure in the range of 12-20 mmHg and the need for dopamine $>5 \mu \mathrm{g} / \mathrm{kg} / \mathrm{min}$ or epinephrine $<0.25 \mu \mathrm{g} / \mathrm{kg} / \mathrm{min}$ to maintain mean arterial blood pressure $>60 \mathrm{mmHg}$ ( $>80 \mathrm{mmHg}$ in previously hypertensive patients). Refractory septic shock is defined as the need for dopamine $>15 \mu \mathrm{g} / \mathrm{kg} / \mathrm{min}$ or epinephrine $>0.25 \mu \mathrm{g} / \mathrm{kg} / \mathrm{min}$ to maintain mean arterial blood pressure $>60 \mathrm{mmHg}$ (> $80 \mathrm{mmHg}$ in previously hypertensive patients) $[9,10]$.

\section{Etiopathogenesis}

Sepsis is a serious medical condition characterised by the activation of the patient's immune system and enhanced production of pro- and anti-inflammatory mediators [11]. The initial patient response to infection (i.e., the interplay between host and microbial agent) is followed by an increased and unregulated immune system response, increased production of proinflammatory mediators such as interleukin-1 (IL-1), interleukin-6 (IL-6), interleukin-8 (IL-8) and tumour necrosis factor-alpha (TNF- $\alpha$ ), and haemodynamic instability accompanied by reduced renal blood flow [11]. The proinflammatory phase is then replaced by the compensatory anti-inflammatory response phase, which blocks the immune system and is characterised by the reduced proliferation and increased apoptosis of lymphocytes, decreased chemotaxis, reduced phagocytosis and increased production of interleukin-10 (IL-10) [11]. The highest concentration of serum mediators (presumption of mediator "peak levels") plays an important part in the pathogenesis of multiple organ dysfunction syndrome in patients with severe sepsis [12-15]. Extracorporeal blood cleansing techniques such as high-volume continuous veno-venous haemofiltration (HVHF) and continuous veno-venous haemodiafiltration using PMMA membrane (PMMA-CHDF) improve the patient's haemodynamic status, reduce the need for vasopressors, restore the balance of immune system response (i.e., the balance between proand anti-inflammatory mediators), reduce the concentration of cell apoptosis-inducing mediators and improve survival in patients with severe sepsis [12-15].

\section{Type 5 Cardiorenal Syndrome: Mechanisms of Aetiopathogenesis}

The relationship between heart and kidneys is important for regulating the volume of arterial blood, which provides blood flow and oxygen supply to the bodily tissues [16-18]. Endothelial dysfunction, arterial vasodilation, decreased myocardial function and reduced blood volume in the arterial circulation, which normally enables renal perfusion, play a major role in causing septic cardiorenal syndrome [16-18]. A reduction in arterial blood volume may occur due to reduced heart rate and/or arterial vasodilation [16-18]. In patients with severe sepsis and septic shock, decreased renal blood flow is caused by arterial vasodilata- 
tion, due to increased production of nitrogen oxides (NO), and decreased myocardial function (increased myocardial concentrations of cytokines/myocardial inflammation and elevated levels of NO in the myocardium) [16-18]. Decreased renal blood flow (reduced blood volume in the arterial circulation, which normally enables renal perfusion) leads to ischaemia of the renal tubular epithelial cells and the development of acute kidney injury (ischaemic acute tubular necrosis) [16-18]. Acute kidney injury and fluid retention in the body have an adverse effect on myocardial function and thus trigger a vicious cycle of kidney and heart disorders [16-18].

\section{Type 5 Cardiorenal syndrome: Diagnosis}

\section{Sepsis biomarkers}

Leukocyte count and C-reactive protein levels are the "gold standard" for diagnosing infection. Normal concentrations of serum procalcitonin are $<0.05 \mathrm{ng} / \mathrm{mL}$ and increases in severe bacterial infections with systemic manifestations [19]. A serum procalcitonin level below $0.5 \mathrm{ng} /$ $\mathrm{mL}$ indicates a possible local infection and inflammation, the absence of a significant inflammatory response and a low risk of progression to severe systemic infection (severe sepsis). Procalcitonin concentrations should be remeasured at 6- to 24-hour intervals due to the possibility of disease development [19]. With serum procalcitonin concentrations ranging from $0.5-2.0 \mathrm{ng} / \mathrm{mL}$, systemic infection (sepsis) is possible, systemic inflammatory response is moderate, and the risk of a progression to severe systemic infection (severe sepsis) is moderate as well. Procalcitonin testing is recommended at 6-24 hours after the last measurement [19]. Serum procalcitonin concentrations ranging from 2-10 $\mathrm{ng} / \mathrm{mL}$ indicate systemic infection, severe systemic inflammatory response and a high risk of progression to severe systemic infection (severe sepsis). Daily procalcitonin measurements are recommended [19]. Procalcitonin values $\geq 10 \mathrm{ng} / \mathrm{mL}$ indicate pronounced systemic inflammatory response, severe sepsis and septic shock, as well as possible multiple organ dysfunction syndrome and a high risk of death. Daily procalcitonin measurements are recommended [19].

\section{Cardiac injury biomarkers}

Determination of the natriuretic peptides BNP and NT-proBNP is needed to diagnose heart failure [20-24]. In patients suffering from chronic kidney disease, serum BNP and NT-proBNP concentrations may be increased, even if clinical manifestation of heart failure is absent due to reduced renal function through decreased renal clearance of natriuretic peptides, myocardial scarring and thickening of the left ventricular wall [20-24]. In patients whose endogenous creatinine clearance is $\geq 60 \mathrm{~mL} / \mathrm{min} / 1.73 \mathrm{~m}^{2}$, BNP values greater than $100 \mathrm{pg} / \mathrm{mL}$ and NT-proBNP values greater than $300 \mathrm{pg} / \mathrm{mL}$ indicate heart failure. If endogenous creatinine clearance is $<60 \mathrm{~mL} / \mathrm{min} / 1.73 \mathrm{~m}^{2}$, then BNP values greater than $200 \mathrm{pg} / \mathrm{mL}$ and NT-proBNP values greater than $1200 \mathrm{pg} / \mathrm{mL}$ indicate heart failure [2024]. Cardiac troponins (cTnI/cTnT) are biomarkers used to demonstrate ischaemia-induced myocardial injury [24, 25 ]. An increase in serum troponin I of $\geq 20 \%$ from baseline indicates ischaemic damage to cardiac cells (cardiomyocytes), while values $\geq 2.0 \mathrm{ng} / \mathrm{mL}$ indicate the development of acute myocardial infarction $[24,25]$.

\section{Renal injury biomarkers}

In the last decade, a number of biomarkers for the early detection of acute kidney injure were discovered: interleukin-18, a kidney injury protein called KIM-1 (kidney injury molecule-1), NGAL (neutrophil gelatinosa-associated lipocalin) and cystatin C [23-25]. Lipocalin is used in clinical practice. NGAL values in urine in excess of $100 \mathrm{ng} / \mathrm{mL}$ two hours after initial event indicate a development of acute kidney damage [23-25]. Cystatin $C$ is a cysteine protease blocker filtered in the glomeruli and completely reabsorbed by proximal tubular epithelial renal cells. An increase in cystatin $\mathrm{C}$ serum concentrations over $0.3 \mathrm{mg} / \mathrm{L}$ in the first 48 hours from the initial event, when compared to baseline, is indicative of the development of acute kidney injury. An increase in the cystatin $C$ serum concentration occurs 1-2 days prior to an increase in serum creatinine, indicating that cystatin $C$ is a more sensitive parameter for the detection of acute kidney injury compared to creatinine[23-25].

\section{Monitoring of patients with severe sepsis and septic shock}

Patients in intensive care units require monitoring of infection parameters (e.g., WBC, CRP, procalcitonin), haemodynamic status parameters (e.g., mean arterial blood pressure, central venous pressure [CVP] or internal jugular vein catheterisation, central venous oxygen saturation $\left[\mathrm{ScvO}_{2}\right]$, pulmonary capillary wedge pressure [PCWP] or pulmonary artery catheterisation), perfusion parameters and organ dysfunction (e.g., serum lactate concentrations, cardiac index $[\mathrm{CI}]$, left ventricular ejection fraction $[\mathrm{EF}]$, diuresis, serum creatinine concentration, platelet count, D-dimer, protein $C$, coagulation status [PT, aPTT, INR]) [26, 27].

\section{Treatment of Type 5 Cardiorenal Syndrome}

\section{Strategic approach to prevention of \\ acute renal injury in sepsis}

Guidelines for the management of severe sepsis highlight the importance of early detection and timely administration of initial treatment within the first six hours of symptom onset to stop the septic cascade. Initial treatment should achieve a central venous pressure (CVP) of 8-12 $\mathrm{mmHg}$, mean arterial blood pressure (MAP) greater than $65 \mathrm{mmHg}$, diuresis greater than $0.5 \mathrm{~mL} / \mathrm{kg} / \mathrm{h}$ and central venous oxygen saturation greater than 70\% [28-32]. The treatment strategy for preventing the development of acute kidney injury includes early goal-directed therapy 
(EGDT), which consists of increased early compensation of blood volume in fluid circulation (i.e., at least $20 \mathrm{~mL} / \mathrm{kg}$ of crystalloids in the first hour of admission followed by $500 \mathrm{~mL}$ crystalloids every 60 minutes in first 6 hours until a central venous pressure of 8 to $12 \mathrm{mmHg}$ is reached) with strict monitoring of patient response [28-32]. When adequate compensation of the circulating blood volume (3000 mL crystalloids) does not lead to increased blood pressure (MAP $<65 \mathrm{mmHg}$ ) and adequate tissue perfusion, a vasopressor treatment is used (dopamine or epinephrine vasopressor therapy) while inotropic therapy (dobutamine) is used when the cardiac index is reduced $\left(\mathrm{CI}<2.2 \mathrm{~L} / \mathrm{min} / \mathrm{m}^{2}\right)$ [28-32]. The saturation of central venous blood reflects a balance in oxygen transport and oxygen consumption; thus, when saturation falls below $70 \%$, even after CVP and MAP are normalised and haematocrit levels are less than $30 \%$, a transfusion of packed red blood cells should be administered [27-32]. In tertiary health care institutions, EGDT is administered in the clinical practice by only $7 \%$ of physicians attending to ICU patients. Training of health care professionals in ICUs plays an important part in the use of early goal-directed therapy in septic patients [28-32].

\section{Sepsis treatment}

Intravenous antibiotic therapy should be initiated immediately within the first hour of determining sepsis symptoms and following the collection of peripheral blood samples. Effects of antibiotic therapy should be evaluated after 48-72 hours using microbiological and clinical data, and antibiotic drugs should be used in accordance with the antibiogram. Source of infection (e.g., abscess, infected necrotic tissue, gastrointestinal perforation) should be removed as soon as possible using the least aggressive surgical method in accordance with adequate patient care [28].

Additional therapies used in the treatment of severe sepsis and septic shock include corticosteroids and recombinant human activated protein C (rhAPC - drotrecogin alfa). Intravenous corticosteroids are recommended in patients with septic shock with relative adrenal insufficiency, as indicated by a cortisol increase of less than $9 \mu \mathrm{g} / \mathrm{dL}$ after the application of $250 \mu \mathrm{g}$ adrenocorticotropic hormone (ACTH) [28]. Hydrocortisone at $50 \mathrm{mg}$ IV q6h for 5 days is to be administered, and the dose should be gradually decreased to $50 \mathrm{mg}$ IV q12h through 6-8 days, followed by an increase to $50 \mathrm{mg}$ IV q24h through 9-11 days [28]. Recombinant human activated protein C (rhAPC) exerts anti-thrombotic, profibrinolytic, anti-inflammatory and cytoprotective effects [28, 32-34]. It is used in patients with sepsis and multiple organ dysfunction syndrome (MODS) or in patients suffering from septic shock with high risk of death (APACHE score > 25) when there is no absolute contraindication due to bleeding (i.e., active internal bleeding, cerebral bleeding in the last three months) at a dose of 24 $\mu \mathrm{g} / \mathrm{kg} / \mathrm{h}$ for $96 \mathrm{~h}$ as an IV infusion [28, 33-35].

Frequent glucose control as well asand continued glucose and insulin infusion to achieve a target blood glucose level of 6-9 $\mathrm{mmol} / \mathrm{L}$ are recommended. Lactic acidosis treatment includes bicarbonate therapy when arterial blood pH decreases below 7.15. Stress ulcer prophylaxis is achieved by hydrogen receptor blockers. Unfractionated heparin and low molecular weight heparin (LMWH) are used for the prevention of deep vein thrombosis in adequate dose monitoring (anti-factor Xa activity) [28, 33].

In patients in intensive care units suffering from severe sepsis and septic shock, acute lung injury and acute kidney injury may occur simultaneously (i.e., multiple organ dysfunction syndrome). Acute lung injury (ALI) (arterial oxygen tension $\mathrm{PaO}_{2}$ and fractional inspired oxygen $\mathrm{FiO}_{2}$ ratio below $300)$, acute respiratory distress syndrome (ARDS) $\left(\mathrm{PaO}_{2} / \mathrm{FiO}_{2}\right.$ ratio below 200) and mechanical ventilation contribute to the development of acute kidney injury (direct interconnectedness between lungs and kidneys) [36-38]. Positive pressure ventilation (PPV) (mechanical ventilation) lowers renal perfusion with its haemodynamic and non-haemodynamic effects. Positive pressure ventilation increases the pressure in the chest cavity and decreases venous return (preload reduced), resulting in decreased heart rate and cardiac output and, consequently, the activation of neurohormonal systems, such as the renin-angiotensin-aldosterone system, sympathetic nervous system and non-osmotic vasopressin system, release and ANP production. Finally, the activation of neurohormonal systems will reduce renal blood flow, decrease glomerular filtration rate (GFR), and increase sodium and water retention in the patient's body [36-38]. Patients in septic shock with acute respiratory failure should undergo protective lung ventilation using low respiratory volume (tidal volume of $6 \mathrm{~mL} /$ $\mathrm{kg}$ of ideal body weight), with end-inspiratory pressure plateau below $30 \mathrm{cmH}_{2} \mathrm{O}$, while using the smallest positive endexpiratory pressure (positive end-expiratory pressure - PEEP) to achieve satisfactory oxygenation [36-38].

\section{Methods of extracorporeal blood cleansing in septic patients}

Sepsis is the leading cause of death in intensive care units. Treatment using extracorporeal blood cleansing techniques change a patient's immune response to the infection by non-selectively removing inflammatory mediators and toxins/bacterial products [39]. Endotoxins and other bacterial products (e.g., lipopolysaccharide [LPS], peptidoglycan, flagellin) stimulate increased production and release of cytokines into the serum of septic patients ("cytokine theory"). Increased concentrations of serum cytokines play an important part in the development of multiple organ dysfunction syndrome (MODS) (the assumption of "peak levels"). Removal of cytokines from a septic patient's serum significantly improves renal and patient outcomes. The two most important extracorporeal cleansing techniques for cytokine blood removal are highvolume continuous veno-venous haemofiltration (HVHF) and continuous veno-venous haemodiafiltration using a polymethylmethacrylate membrane haemofilter (PMMACDHF) [39]. 


\section{Treatment initiation time for dialysis} supportive therapy

In patients with AKI, it is necessary to assess the severity of injury and the presence of absolute indications for treatment with renal replacement therapy (RRT) (dialysis supportive therapy). Absolute indications for initiation of dialysis treatment include: serum urea concentration $\geq 36$ $\mathrm{mmol} / \mathrm{L}$, complications of uraemia (uremic encephalopathy, uremic pericarditis), resistant hyperkalaemia $\left(\mathrm{K}^{+}>6.5\right.$ $\mathrm{mmol} / \mathrm{L}$ with or without electrocardiographic changes), hypermagnesaemia $\left(\mathrm{Mg}^{2+} \geq 4.0 \mathrm{mmol} / \mathrm{L}\right.$ and absence of deep tendon reflexes), severe metabolic acidosis (arterial blood $\mathrm{pH} \leq 7.15$ ) and volume overload (pulmonary oedema) resistant to diuretics in the presence of oligoanuric AKI [40]. In patients with severe AKI (RIFLE-F or AKIN III), initiation of dialysis supportive therapy is to be considered, and increased monitoring and treatment is recommended in those with mild/moderate AKI (RIFLE-R or I, AKIN I or II). Prior to making a decision to initiate RRT treatment in patients with mild or moderate renal injury, the treatment objectives, primary diagnosis, severity of the patient's clinical condition, renal functional reserve and the need to prevent development of complications should be taken into account. In patients with sepsis (high catabolism), there is a potential benefit of early initiation of dialysis treatment [40]. When making the decision to start dialysis treatment with supportive therapy, clinical conditions that adversely affect renal function in ICU patients, such as increased intra-abdominal pressure, mechanical positive pressure ventilation and use of nephrotoxins and radiocontrast agents, should be considered [40].

\section{Selecting modes of dialysis supportive therapy}

Patients with AKI are treated with numerous dialysis modalities, employed to remove uremic toxins and substances from the blood using mechanisms of diffusion (peritoneal dialysis, standard haemodialysis, slow low efficiency dialysis [SLEDD], continuous veno-venous haemodialysis), convection (intermittent haemofiltration, continuous veno-venous haemofiltration [CVVHF], continuous veno-venous high-volume haemofiltration [HVHF]), a combination of diffusion and convection (intermittent haemodiafiltration, slow low-efficiency diafiltration [SLEDDf], continuous veno-venous haemodiafiltration [CVVHDF]) and adsorption (continuous veno-venous haemodiafiltration using a polymethylmethacrylate membrane haemofilter [PMMA-CHDF]) [41-49].

Intermittent haemodialysis is performed in patients who are haemodynamically stable, with high levels of nitrogen and severe hyperkalaemia, and in patients with an increased risk of bleeding. Individual session doses for conventional intermittent (3 times per week) and enhanced intermittent ( 6 time per week) haemodialysis are single pool $\mathrm{Kt} / \mathrm{V}$ index $\geq 1.2[47,48]$. Intermittent haemodialysis has little impact on most of the major inflammatory cytokines. Hybrid modes of dialysis therapy, such as slow low-efficiency dialysis (SLEDD), provide excellent clearance of low molecular weight uraemic toxins, moderate clearance of medium molecular weight uremic toxins and good haemodynamic stability of patients [47, 48]. Individual session doses for conventional SLEDD (3 times per week for 6-12 hrs) and enhanced SLEDD (6 times per week for 6-12 hrs) are a single pool Kt/V in$\operatorname{dex} \geq 1.2$ (single pool Kt/V index $=1.2-1.4$ ) [47, 48]. SSC (Surviving Sepsis Campaign) guidelines recommend that, in the absence of haemodynamic instability, intermittent and continuous dialysis treatment modalities should be equally considered [49]. Haemodynamically unstable patients (septic shock) in intensive care units suffering from AKI, with multiple organ dysfunction syndrome, elevated levels of serum cytokines (interleukin- 6 concentrations $\geq$ $1000 \mathrm{pg} / \mathrm{mL}$ ), increased catabolism and hypervolaemia require treatment modalities of continuous renal replacement therapy (CRRT) [41-49].

Most immune system mediators are substances of medium molecular weight (5-50 kD), soluble in water and removable using continuous renal replacement modalities. The standard dialysis dose in continuous veno-venous haemofiltration (CVVHF) and continuous veno-venous haemodiafiltration (CVVHDF) is $20-30 \mathrm{~mL} / \mathrm{kg} / \mathrm{h}$, while in patients with sepsis and acute kidney injury the dose of continuous dialysis modality should be $35 \mathrm{~mL} / \mathrm{kg} / \mathrm{h}$ [41-45, 50, 51]. High-volume continuous veno-venous haemofiltration (HVHF) is used for the removal of pro- and antiinflammatory mediators, due to the high convective transport, at $>35 \mathrm{~mL} / \mathrm{kg} / \mathrm{h}$. It may be used continuously, with an ultrafiltration rate of $50-70 \mathrm{~mL} / \mathrm{kg} / \mathrm{h}(35-80 \mathrm{~mL} / \mathrm{kg} / \mathrm{h})$ over 24 hours, or as pulse high-volume haemofiltration, with an ultrafiltration rate of $85-100 \mathrm{~mL} / \mathrm{kg} / \mathrm{h}(100-120 \mathrm{~mL} /$ $\mathrm{kg} / \mathrm{h}$ ) over 4-8 hours, followed by the standard dose afterwards [48-50]. High-volume haemofiltration significantly reduces the concentration of inflammatory mediators and restores the balance between inflammatory syndrome and compensatory anti-inflammatory systemic responses [41$45,50,51]$.

Continuous veno-venous haemodiafiltration with PMMA membrane (PMMA-CHDF) is administered within 24 hours of developing septic shock, and it removes cytokines via the adsorption process to the dialysis membrane matrix (i.e., cytokine adsorption to highly specific membranes/membranes with high cytokine removal capacity). It is effective in the treatment of clinical conditions associated with increased concentration of serum cytokines (interleukin- 6 concentrations $6 \geq 1000 \mathrm{pg} / \mathrm{mL}$ ), such as septic shock, multiple organ dysfunction syndrome caused by sepsis, acute respiratory distress syndrome and severe acute pancreatitis $[41-45,50,51]$. The results of clinical trials (EUPHAS Study) show that PMMA-CHDF is more effective in cleansing blood of patients with severe sepsis and septic shock compared to PMX-DHP (Polymyxin-B direct haemoperfusion), which plays an important part in the removal of endotoxin (lipopolysaccharide) from the blood of septic patients $[41-45,50,51]$. 
Continuous modalities of dialysis supportive therapy should provide haemodynamic stability and homeostasis of the immune system. It provides an opportunity to use CRRT not only as supportive therapy, but also but also as a treatment to prevent injury progression and the development of multiple organ dysfunction syndrome in septic patients $[50,51]$.

\section{Conclusion}

The early identification of patients at increased risk for developing acute kidney injury and timely implementation of an appropriate treatment plan can prevent the development of acute kidney injury and reduce morbidity and mortality in septic patients. Haemodynamically unstable patients (septic shock) in intensive care units suffering from acute kidney injury, on mechanical respiration, with multiple organ dysfunction syndrome, elevated levels of serum cytokines, increased catabolism and hypervolaemia require treatment modalities of continuous renal replacement therapy. Well-controlled, prospective, randomised clinical trials should more precisely determine the place and role of various modalities of dialysis therapy in patients with sepsis and AKI in intensive care units.

Acknowledgments: The authors would like to express their deepest gratitude to the Serbian Ministry of Science and Technological Development for their Grant N0175014, which was used as one of the sources to financially support the study.

\section{REFERENCES}

1. Ronco C, House AA, Haapio M. Cardiorenal syndrome: refining the definition of a complex symbiosis gone wrong. Intensive Care Med 2008; 34(5): 957-62.

2. Ronco C, Haapio M, House AA, Anaveker N, Bellomo R. Cardiorenal Syndrome. J Am Coll Cardiol 2008; 52(19): 1527-39.

3. Ronco C, Chionh C-Y, Maapio M, Anavekar NS, House A, Bellomo R. The Cardiorenal Syndrome. Blood Purif 2009; 27(1): 114-26.

4. Ronco C, McCullough, Anker SD, Anand I, Aspromonte N, Bagshaw SM, et al. Cardio-renal syndromes: report from the consensus conference of the Acute Dialysis Quality Initiative. Eur Heart J 2010; 31(6): 703-11.

5. Petrović D, Jagić N, Miloradović V, Nikolić A, Stojimirović B. Cardiorenal syndrome - definition, classification and basic principles of therapy. Ser J ExpClin Res 2010; 11(2): 67-71.

6. Petrović D, Milovanović D, Miloradović V, Nikolić A, Petrović M, Đurđević P, Poskurica M. Kardio-renalni sindrom tip 2: etiopatogeneza, dijagnostika i lečenje. Medicinski Časopis 2012; 46:(1): 30-4.

7. Ronco C. Introduction. In: Acute Blood Purification. Contrib Nephrol. Suzuki H, Hirasawa H (eds). Basel, Karger 2010; 166: 1-3.
8. Stoneking L, Denninghoff K, DeLuca L, Keim SM, Munger B. Sepsis Bundles and Compliance With Clinical Guidelines. J Int Care Med 2011; 26(3): 172-82.

9. Dollins MD. Part 2: Circulation. In: Critical Care Nephrology. Molitoris B, ed. London: Remedica, 2005: 21-42.

10. Hunter JD, Doddi M. Sepsis and the heart. Br J Anaesth 2010; 104(1): 3-11.

11. Zarjou A, Agarwal A. Sepsis and Acute Kidney Injury. J Am Soc Nephrol 2011; 22(6): 999-1006.

12. Ronco C, Brendolan A, Bellomo R, Ricci Z, Bonello M, Ratanarat R, et al. The Rationale for Extracorporeal Therapies in Sepsis. Advances in Sepsis 2004; 4(1): 2-10.

13. House AA, Ronco C. Extracorporeal Blood Purification in Sepsis and Sepsis-Related Acute Kidney Injury. Blood Purif 2008; 26(1): 30-5.

14. Venkatarman R, Subramanian S, Kellum JA. Clinical review: Extracorporeal blood purification in severe sepsis. Crit Care 2003; 7(2): 139-45.

15. Claudio R, Tetta C, Mariano F, Wratten ML, Bonello M, Bordoni $\mathrm{V}$, et al. Interpreting the Mechanisms of Continuous Renal Replacement Therapy in Sepsis: The Peak Concentrations Hypothesis. Artif Organs 2003; 27(9): 792-80.

16. Chelazzi C, Villa G, De Gaudio AR. Cardiorenal Syndromes and Sepsis. Int J Nephrol 2011: ID 652967.

17. Schrier RW. Role of Diminished Renal Function in Cardiovascular Mortality. J Am Coll Cardiol 2006; 47(1): 1-8.

18. Schrier RW. Decreased Effective Blood Volume in Edematous Disorders: What Does This Mean? J Am SocNephrol 2007; 18(7): 2028-31.

19. Čanović P, Nešić $L j$, Tomović M, Čanović D. Dijagnostički i prognostički značaj merenja prokalcitonina u toku septičkih stanja. Medicinski Časopis 2006; 40(3): 52-7.

20. Anwaruddin S, Lloyd-Jones DM, Baggish A, Chen A, Krauser D, Tung $\mathrm{R}$, et al. Renal function, congestive heart failure, and amino-terminal pro-brain natriuretic peptide measurement: results from the ProBNP Investigation of Dyspnea in the Emergency Department (PRIDE) Study. J Am Coll Cardiol 2006; 47(1): 91-7.

21. David S, Kümpers P, Seidler V, Biertz F, Haller H, Fliser D. Diagnostic value of $\mathrm{N}$-terminal pro-B-type natriuretic peptide (NT-proBNP) for left ventricular dysfunction in patients with chronic renal disease stage 5 on hemodialysis. Nephrol Dial Transplant 2008; 23(4): 1370-7.

22. Valle R, Aspromonte N. Use of Brain Natriuretic Peptide and Bioimpedance to Guide Therapy in Heart Failure Patients. In: Fluid Overload: Diagnosis and Management. Ronco C, Costanzo MR, Bellomo R, Maisel AS (eds). ContribNephrol. Basel, Karger, 2010, vol 164, pp 209-16.

23. Maisel AS, Katz N, Hillege HL, Shaw A, Zanco P, Bellomo $\mathrm{R}$, et al and for the Acute Dialysis Quality Initiative (ADQI) consensus group. Biomarkers in kidney and Heart disease. Nephrol Dial Transplant 2011; 26(1): 62-74.

24. Petrović D, Jagić N, Miloradović V, Stojimirović B. Clinical importance of biochemical markers of cardiac damage in hemodialysis patients. Ser J ExpClin Res 2008; 9(1): 5-8. 
25. Lassus JPE, Nieminen MS, Peuhkurinen K, Pulkki K, Siirila-Waris K, Sund R, et al. Markers of renal function and acute kidney injury in acute heart failure: definitions and impact on outcomes of the cardiorenal syndrome. Eur Heart J 2010; 31(22): 2791-8.

26. Liu KD. Critical Care Nephrology: Core Curriculum 2009. Am J Kidney Dis 2009; 53(5): 898-910.

27. Moranville MP, Mieure KD, Santayana EM. Evaluation and Management of Shock States: Hypovolemic, Distributive, and Cardiogenic Shock. J Pharm Pract 2011; 24(1): 44-60.

28. Jevđić J, Šurbatović M, Drakulić-Miletić S, Vukićević V. Primena novih terapijskih protokola u lečenju sepse i septičnog šoka u jedinicama intenzivnog lečenja kliničkog centra u Kragujevcu. Srp Arh Celok Lek 2008; 136(5-6): 248-52.

29. Rivers E, Nguyen B, Havstad S, Ressler J, Muzzin A, Knoblich B, et al. Early Goal-Directed Therapy in the Treatment of Severe Sepsis and Septic Shock. N Engl J Med 2001; 345(19): 1368-77.

30. Otero RM, Nguyen HB, Haung DT, Gaieski DF, Goyal M, Gunnerson KJ, et al. Early Goal-Directed Therapy in Severe Sepsis and Septic Shock Revisited. Chest 2006; 130(5): 1579-95.

31. Petrović D. Akutno oštećenje bubrega: etiologija, dijagnostika i lečenje. Medicinska Istraživanja 2011; 45(3): 7-13.

32. Lukić S, Petrović D. Prevencija akutnog oštećenja bubrega u jedinicama intenzivnog lečenja. Med Čas 2012; 46(2): 100-4.

33. Rudis MI, Rowland KL. Current Concepts in Severe Sepsis and Septic Shock. J Pharm Pract 2005; 18(5): 351-62.

34. Gupta A, Williams MD, Macias W, Molitoris BA, Grinelli BW. Activated Protein C and Acute Kidney Injury: Selective Targeting of PAR-1. Curr Drug Targ 2009; 10(12): 1212-26.

35. Bernard GR, Vincet JL, Laterre PF, LaRosa SP, Dhainaut JF, Lopez-Rodriguez A, et al. Efficacy and safety of recombinant human activated protein $\mathrm{C}$ for severe sepsis. N Eng J Med 2001; 344(10): 699-709.

36. Ronco C, Kellum JA, Bellomo R, House AA. Potential interventions in Sepsis-Related Acute kidney Injury. Clin J Am Soc Nephrol 2008; 3(2): 531-44.

37. Koyner JL, Murray PT. Mechanical Ventilation and the Kidney. Blood Purif 2010; 29(1): 52-68.

38. Cawley MJ. Mechanical Ventilation: Introduction for the Pharmacy Practitioner. J Pharm Pract 2011; 24(1): 7-16.
39. Rimmele T, Kellum JA. Clinical Rewiev: Blood purification for sepsis. Critical Care 2011; 15(1): 205.

40. Bagshaw SM, Cruz DN, Gibney RTN, Ronco C. A proposed algorithm for initiation of renal replacement therapy in adult critically ill patients. Crit Care 2009; 13(6): 317-25.

41. Nakada T, Matsuda K, Sadahiro T, Nakamura M, Abe R, Hirasawa H. Continuous Hemodiafiltration with PMMA Hemofilter in the Treatment of Patients with Septic Shock. Mol Med 2008; 15(5-6): 257-63.

42. Davenport A. Dialytic Treatment for Sepstic Patients with Acute Kidney Injury. Kidney Blood Press Res 2011; 34(4): 218-24.

43. Kawanishi H. Terminology and Classification of Blood Purification in Critical Care in Japan. Indications for Blood Purifications in Critical Care. In: Acute Blood Purification. Suzuki H, Hirisawa H (eds). ContribNephrol. Basel, Karger, 2010, vol. 166, pp 11-20.

44. Hirasawa H. Indications for Blood Purifications in Critical Care. In: Acute Blood Purification. Suzuki H, Hirisawa H (eds). Contrib Nephrol. Basel, Karger, 2010, vol. 166, pp 21-30.

45. Abe R, Oda S, Shinozaki K. Continuous Hemodiafiltration Using a Polymethyl Methacrylate Membrane Hemofilter for Severe Acute Pancreatitis. In: Acute Blood Purification. Contrib Nephrol. Suzuki H, Hirasawa H (eds). Basel, Karger 2010; 166: 54-63.

46. Prowle JR, Bellomo R. Continuous renal replacement therapy: recent advances and future research. Nat Rev Nephrol 2010; 6(9): 521-9.

47. John S, Eckardt K-U. Replacment Therapy in the Treatment of Acute Renal Failure - Intermitent and Continuous. Semin Dial 2006; 19(6): 455-64.

48. John S, Eckardt K-U. Renal Replacement Strategies in the ICU. Chest 2007; 132(4): 1379-88.

49. Ricci Z, Picca S, Guzzo I, Ronco C. Kidney diseases beyond nephrology: intensive care. Nephrol Dial Transplant 2011; 26(2): 448-54.

50. Joannidis M. Continuous Renal Replacement Therapy in Sepsis and Multisystem Organ Failure. Semin Dial 2009; 22(2): 160-4.

51. Prowle JR, Schneider and Bellomo R. Optimal dose of continuous renal replacement therapy in acute kidney injury. Crit Care 2011; 15(2): 207-14. 